\title{
Effect of thermo-mechanical parameters on the mechanical properties of Eurofer97 steel for nuclear applications
}

https://doi.org/10.1515/eng-2018-0040

Received October 17, 2017; accepted November 17, 2017

\begin{abstract}
Eurofer97 steel has been recognised in Europe as the reference steel for nuclear application under high radiation density. Following to this a detailed knowledge of microstructure evolution is required for such steel after thermo-mechanical processing. In this paper the effect of thermo-mechanical parameters on the mechanical behavior of Eurofer97 was investigated by hot rolling and heat treatment on pilot scale. Results show a strong effect was found of reheating temperature before rolling on the material hardness, due to an increase of hardenability following the austenite grain growth. A minor effect was found of the hot reduction and the tempering temperature in the total investigated deformation range. A loss of impact energy was found coupled with the hardness increase.
\end{abstract}

Keywords: Nuclear application steels, mechanical properties, quenching and tempering

\section{Introduction}

In Europe EUROFER97 has been recognised as reference steel [1] for the nuclear costructions under high radiation density for first wall of a fast breeder reactors as well as in other high stressed primary structures such as the divertors, blanklet and vessels, [2-7]. One of the main reason for this selection are the EUROFER97 steel high mechanical properties at service temperatures coupled with the

\footnotetext{
^Corresponding Author: Andrea Di Schino: Dipartimento di Ingegneria, Università di Perugia, 01625 Perugia, Italy, formerly Centro Sviluppo Materiali SpA, Roma, Italy, E-mail: andrea.dischino@unipg.it Claudio Testani: CALEF-ENEA CR-Casaccia, Via Anguillarese 301 S.P. 059, 00123 Santa Maria di Galeria, Rome, Italy, formerly Centro Sviluppo Materiali SpA, roma, Italy

Luciano Pilloni: ENEA CR-Casaccia, Via Anguillarese 301 S.P. 059, 00123 Santa Maria di Galeria, Rome, Italy
}

low or reduced activation (RAFM) characteristic under radiation with the result of low mechanical properties loss. This material behavior has been reported in many literature studies and important initiatives are still ongoing [810]. The reduced activation ferritic/martensitic steels differ from conventional Cr-Mo steels because of $\mathrm{W}$ presence instead of Mo. With this respect EUROFER 97 steel is essentially a low carbon steel with $9 \mathrm{Cr}(\% \mathrm{wt})$ with controlled Ta and $\mathrm{V}$ (favoring grain refinement and enhancing precipitation state) content that can have an important influence on resulting final mechanical properties in carbon and stainless steels [11-21]. EUROFER 97 reference chemical composition is reported in Table 1.

Moreover, other elements such us $\mathrm{Mo}, \mathrm{Nb}, \mathrm{Ni}, \mathrm{Cu}$ and $\mathrm{N}$, are maintained as low as possible. The irradiation tests carried on EUROFER 97 show that the resulting radioactivity levels over two orders of magnitude under those recorded for conventional $\mathrm{Cr}$ steels [22-24], with low affected mechanical and physical properties $[9,10]$. Low activation steels have a fully austenite structure when are austenitized in the temperature range from $850^{\circ} \mathrm{C}$ to $1200^{\circ} \mathrm{C}$. Austenite phase transforms to martensite phase during air cooling or rapid cooling (quenching) to room temperature, and then steels are tempered to obtain a good combination of strength, ductility, and toughness. However, the use of these materials during long-time at high temperatures (thermal ageing) can produce microstructural changes (new precipitates, grain growth, segregation, etc.) which can significantly affect their mechanical properties (tensile, Charpy- $\mathrm{V}$, fracture toughness, low cycle fatigue, etc.) [23-25]. For these reasons, an exhaustive knowledge of the metallurgical characteristics of these steels before and after thermal ageing is considered essential. In RAFM steels the desirable properties (low sensibility to radiation damage) are controlled by mean of the martensitic transformation thermal cycle design, and in particular are due the microstructure refinement (increase of the low and high angle boundaries) with clear advantages for applications in nuclear reactors [1]. The martensitic transformation occurs in steels by mean of a non- 
Table 1: EUROFER 97 chemical composition (mass, \%) (Ni, Mo, $\mathrm{Cu}, \mathrm{Nb}, \mathrm{Al}, \mathrm{B}, \mathrm{Co}$ : as low as possible (ALAP), $\mathrm{S}=20 \mathrm{ppm}, \mathrm{P}=100 \mathrm{ppm}$ )

\begin{tabular}{cccccccc}
\hline $\mathrm{C}$ & $\mathrm{Mn}$ & $\mathrm{Cr}$ & $\mathrm{V}$ & $\mathrm{Ta}$ & $\mathrm{W}$ & $\mathrm{N}$ & $\mathrm{As}+\mathrm{Sn}+\mathrm{Sb}+\mathrm{Zr}$ \\
\hline 0.11 & 0.4 & 9.0 & 0.2 & 0.07 & $1.0-2.0$ & 0.030 & $\mathrm{ALAP}, 0,05$ \\
\hline
\end{tabular}

diffusional transformation when the material is cooled from above $A_{c 1}$ to a sufficiently lower temperature $\left(M_{s}\right)$ with cooling rate higher than the "critical cooling-rate": in these condition the transformation is lead from the energy decrease due to the metastable face-centered cubic (FCC) phase arrangement in the new stable body-centered cubic (BCC) phase [2]. The conventional EUROFER 97 thermal treatment consists in normalization at $980^{\circ} \mathrm{C} / 30 \mathrm{~min}$ utes + temper at $760^{\circ} \mathrm{C} / 90^{\prime} /$ air-cooling [12].

In this work the effect of thermo-mechanical treatment on the microstructure is analyzed, aimed to achieve higher tensile properties in order to evaluate its feasibility as possible structural material for fusion applications. In particular, the effect of thermo-mechanical and tempering treatment at $\mathrm{T}=750^{\circ} \mathrm{C}$ and $720^{\circ} \mathrm{C}$ is analyzed in comparison with standard tempering condition for improving fusion applications ranges.

\section{Methods}

Starting from a EUROFER 97 rolled plate with the steel chemical composition reported in Table 1, the effect of reheating temperatures (before hot rolling) and rolling temperatures is analyzed. The plate was hot rolled on a pilot scale (diameter of working roll $=450 \mathrm{~mm}$ ) adopting two different reheating temperatures $\left(1075^{\circ} \mathrm{C}\right.$ and $1175^{\circ} \mathrm{C}$ for 60 minutes), together with two finish rolling temperatures $\left(750^{\circ} \mathrm{C}\right.$ and $\left.650^{\circ} \mathrm{C}\right)$ and two different total reductions (30\% and $40 \%)$. Reductions were in all cases given in 3 passes. The plate was air-cooled (cooling rate about $5^{\circ} \mathrm{C} / \mathrm{s}$ ). The effect of tempering treatment after hot rolling is also analyzed (in the temperature range $720^{\circ} \mathrm{C}-760{ }^{\circ} \mathrm{C}$ ). Hardness and Charpy-V impact tests at $-20^{\circ} \mathrm{C}$ are carried out on transverse specimens. Microstructure is analyzed by light microscopy after Vilella etching.

\section{Results and discussion}

A limited effect was found following to the variation of rolling temperature, reheating temperature and reduction in the considered range (Figure 1).
The effect of tempering following the hot rolling as a function of thermo-mechanical parameters is reported in Table 2. Results show that higher hardness values are found after re-heating at higher temperature $\left(1175^{\circ} \mathrm{C}\right)$.

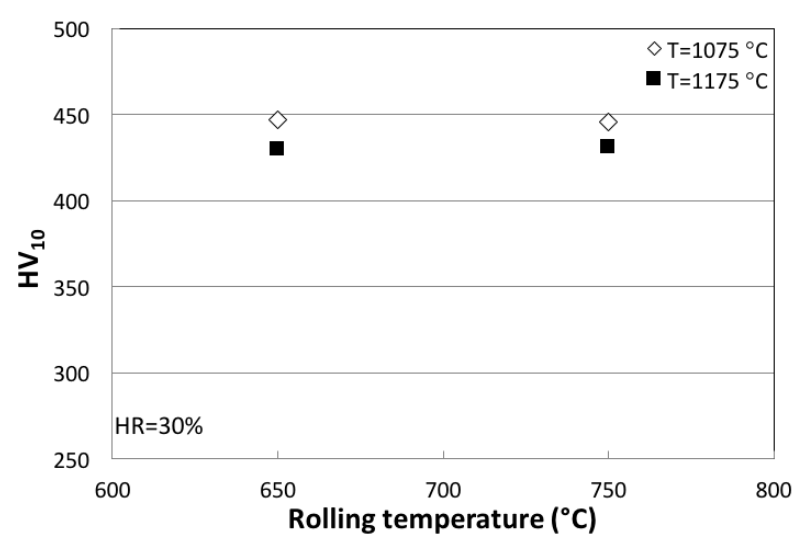

(a)

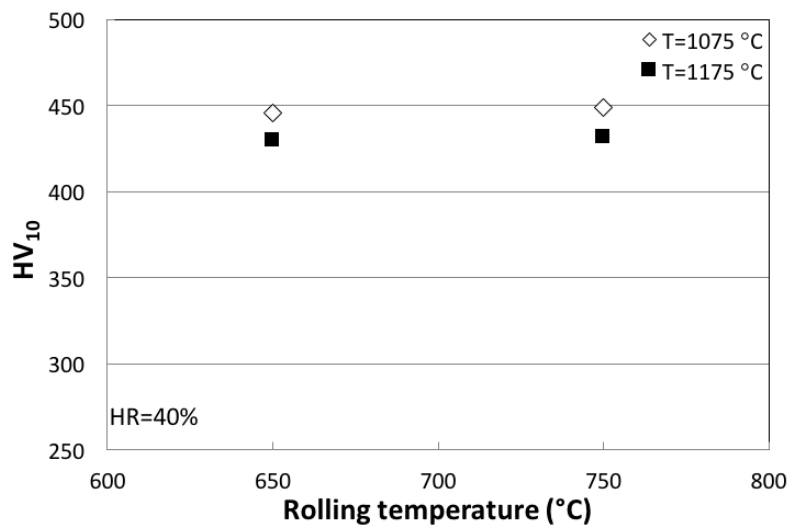

(b)

Figure 1: Effect of thermo-mechanical parameters on EUROFER 97 hardness (a: $30 \%$ hot reduction, b: $40 \%$ hot reduction)

This is due to an improvement of hardenability following an increase of austenite grain size. In Figure 2 the microstructure evolution is reported for specimens 1-8 after tempering at $\mathrm{T}=720^{\circ} \mathrm{C}$. Results show a clear effect of reheating temperature on austenite grain growth. Average grain size was about $20 \mu \mathrm{m}$ in the case of specimens austenitised at $1075^{\circ} \mathrm{C}$ and about $200 \mu \mathrm{m}$ after austenitisation at $1175^{\circ} \mathrm{C}$. The same effect is independent and effective also in the case of specimens after tempering at $\mathrm{T}=760^{\circ} \mathrm{C}$. 
Table 2: Effect of tempering after hot rolling

\begin{tabular}{|c|c|c|c|c|c|}
\hline Specimen n. & $\begin{array}{c}\text { Reheating } \mathrm{T} \\
\left({ }^{\circ} \mathrm{C}\right)\end{array}$ & $\begin{array}{c}\text { Rolling T } \\
\left({ }^{\circ} \mathrm{C}\right)\end{array}$ & $\begin{array}{l}\text { Hot reduction, } \\
(\%)\end{array}$ & \multicolumn{2}{|c|}{ Tempering $\mathrm{T}\left({ }^{\circ} \mathrm{C}\right)$} \\
\hline & & & & 720 & 760 \\
\hline & & & & $\mathrm{HV}_{10}$ & $\mathrm{HV}_{10}$ \\
\hline 1 & \multirow{4}{*}{1075} & \multirow{2}{*}{750} & 30 & 278 & 225 \\
\hline 2 & & & 40 & 267 & 225 \\
\hline 3 & & \multirow{2}{*}{650} & 30 & 271 & 228 \\
\hline 4 & & & 40 & 270 & 234 \\
\hline 5 & \multirow{4}{*}{1175} & \multirow{2}{*}{750} & 30 & 284 & 251 \\
\hline 6 & & & 40 & 290 & 246 \\
\hline 7 & & \multirow{2}{*}{650} & 30 & 298 & 254 \\
\hline 8 & & & 40 & 306 & 259 \\
\hline
\end{tabular}

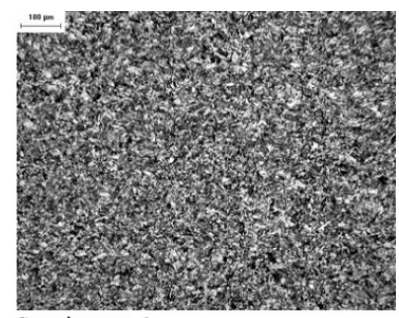

Specimen $\mathrm{n} .1$

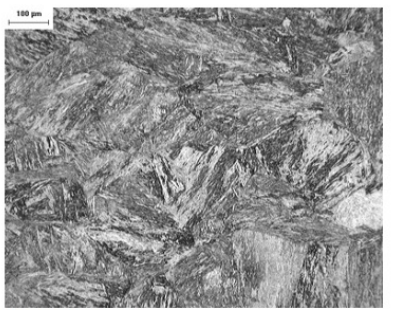

Specimen $n .5$

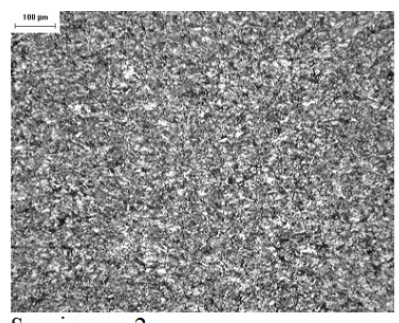

Specimen $n .2$

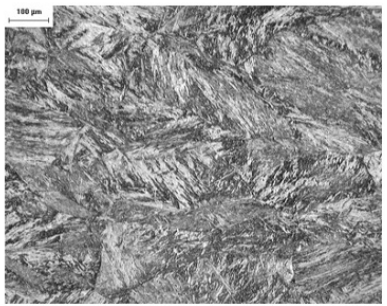

Specimen n.6

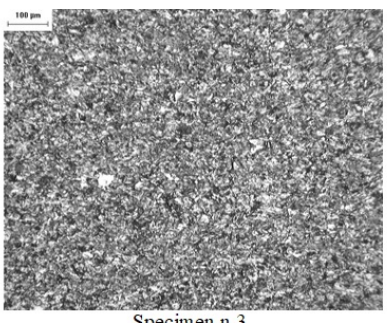

Specimen $\mathrm{n} .3$

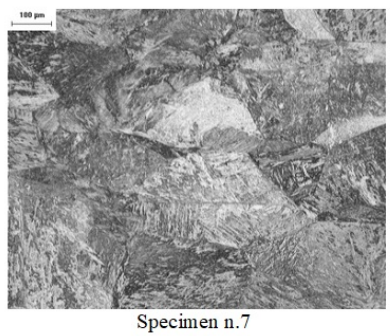

Specimen n.7

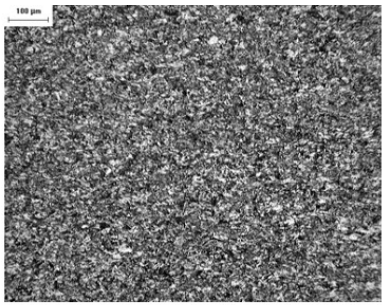

Specimen n.4

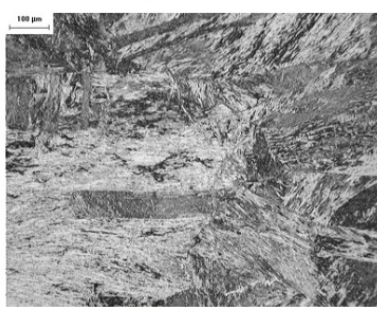

Specimen $\mathrm{n} .8$

(a)

(b)

Figure 2: (a) Microstructure evolution of EUROFER 97 after thermo-mechanical processing according to Table 2 (Final rolling temperature $=750^{\circ} \mathrm{C}$; (b)Microstructure evolution of EUROFER 97 after thermo-mechanical processing according to Table 2 (Final rolling temperature $=650^{\circ} \mathrm{C}$

At the same time larger austenitic grain size (due to higher austenitization temperature) leads to an intense decrease of impact toughness behavior. In Table 3 the effect of austenite grain size on impact energy is reported: a decrease of CVN energy is found as hardness is increased, as expected, following to an increase of critical cleavage stress [26, 27].

\section{Conclusions}

The effects of thermo-mechanical parameters on the mechanical behavior of EUROFER 97 were investigated by hot rolling and tempering heat treatment on pilot scale. Results show that EUROFER 97 is a high sensitive material to the thermo-mechanical process and thermal post process cycle. In fact, a strong effect was found of reheating temperature before rolling on the material hardness, due to an increase of hardenability following the austenite grain growth. A poor effect of the hot reduction and of the following tempering temperature was detected in the total thickness reduction range: $30-40 \%$. An intense loss of CV-N impact energy is found coupled with the hardness increase when the reheating temperature is increased from $1075^{\circ} \mathrm{C}$ up to $1150^{\circ} \mathrm{C}$. 
Table 3: Effect of reheating temperature on Charpy-V notch toughness

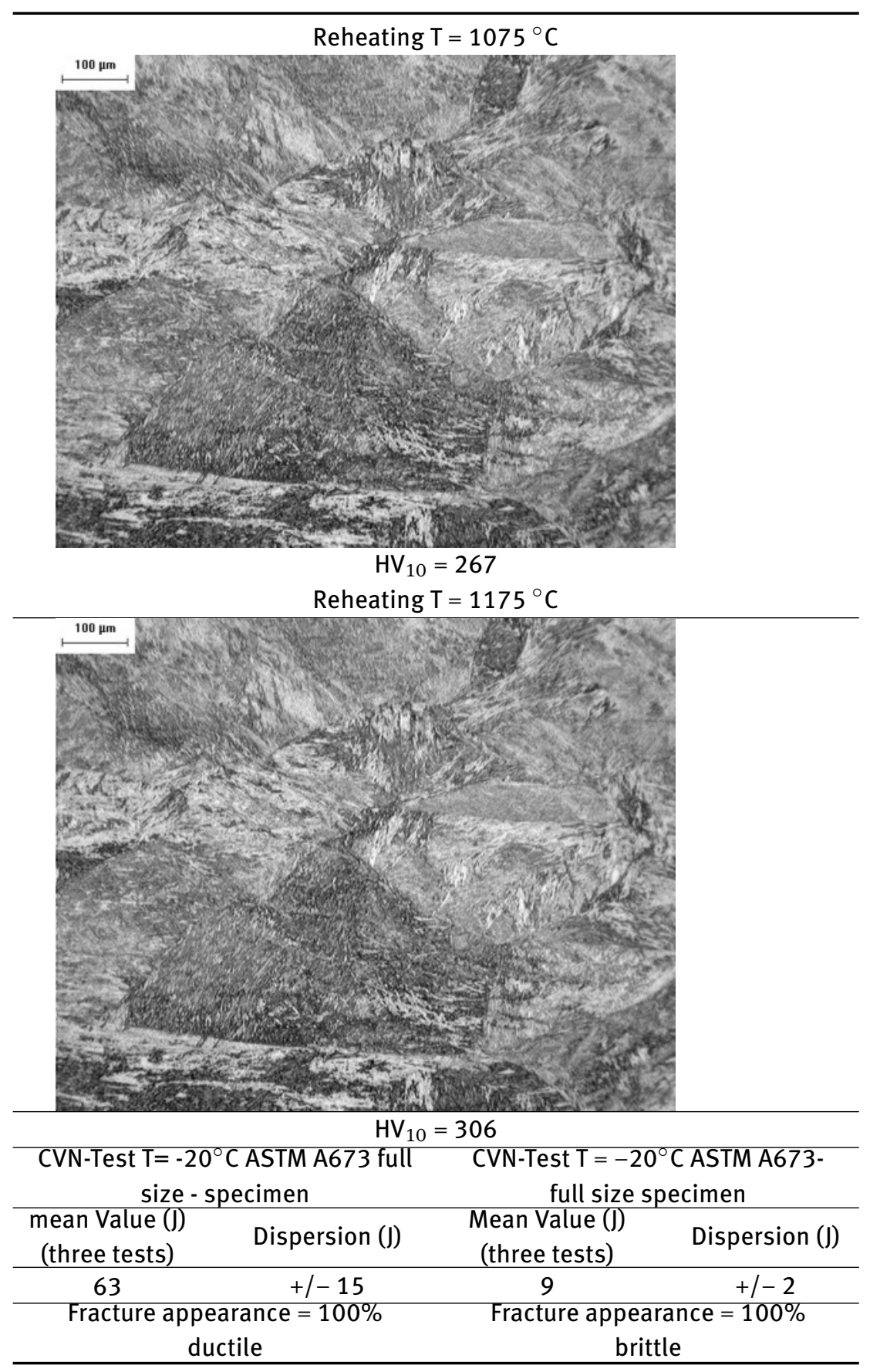

Acknowledgement: The present paper summarise some of the research results obtained under EUROFUSION funded activities.

\section{References}

[1] Rieth M., Dafferner B., Rohrig H.D., Wassilew C., Charpy impact properties of martensitic $10.6 \mathrm{Cr}$ steel after neutron exposure, Fusion Engineering and Design, 1995, 29, 365-370

[2] Zilnyk K.D., Oliveira V.B., Sandim H.R.Z., Möslang A., Raabe D., Martensitic transformation in eurofer-97 and ODS-eurofer steels: A comparative study, J. Nucl. Mater., 2015, 462, 360-367 
[3] Möslang A., IFMIF: the intense neutron source to qualify materials for fusion reactors Comptes Rendus Physique, 2008, 9, 457-468

[4] S.J. Zinkle, Was G.S., Materials challenges in nuclear energy, Acta Mater., 2013, 61, 735-738

[5] Guerin Y., Was G.S, Zinkle S.J., Materials Challenges for Advanced Nuclear Energy Systems, MRS Bulettin, 2009, 34, 10-14

[6] Marcus G.H., Progress in Nuclear Energy, Innovative Nuclear Energy Systems and the Future of Nuclear Power.2008, 50, 92-96

[7] Ehrlich K., Konys J., Heiinheimo L., Recent progress in research on tungsten materials for nuclear fusion applications in Europe, J. Nucl. Mater., 2004, 327,140-147

[8] Klueh R.L., Donald D.R. Harries, High Chromium Ferritic and Martensitic Steels for Nuclear Applications, ASTM Stock number, 2001

[9] Tan L., Hoelzer L., Busby J.T., Sokolov M.A., Klueh R.L., Microstructure control for high strength $9 \mathrm{Cr}$ ferritic-martensitic steels, J. Nucl. Mater., 2012, 422, 45-50

[10] Tan L., Ren X., Allen T.R., Corrosion behaviour of 9-12\% Cr ferritic martensitic steels, Corrosion Science, 2010, 52, 1520-1528

[11] Dulieu D., Tupholme K., Butterworth G.J., J. Nucl. Mater., 1986, 141-143, 1097-1101

[12] Was G.S., Fundamentals of Radiation Materials Science. Metals and Alloy (Second editon), Springer, Berlin, 2016 DOI: 10.1007/978-1-4939-3438-6

[13] Declan B., Nuclear power energy Nature, 2004, 429, 238-240

[14] Kvačkaj T., Bidulský R., Kováčová A., Ileninová J., Bidulská J., Analysis of metallic materials for iter with emphasis on $\mathrm{Cu}$ alloys, Acta Metallurgica Slovaca, 2014, 20, 397-404

[15] Di Schino A., Di Nunzio P.E., Metallurgical aspects related to contact fatigue phenomena in steels for back-up rolls, Acta Metallurgica Slovaca, 2017, 23, 62-71

[16] Hilger L., Boulnat X., Hoffman J., Testani C., Bergner F., Ferraro F., Ulbricht A., Fabrication and characterization of oxide dispersion strengthened (ODS) $14 \mathrm{Cr}$ steels consolidated by means of hot isostatic pressing, hot extrusion and spark plasma sintering, J. Nucl. Mater., 2016, 472, 206-214
[17] Gabrel J., Coussement C., Verelst L., Blum R., Chen Q., Testani C., Superheater materials testing for USC boilers: Steam side oxidation rate of 9 advanced materials in industrial conditions, Materials Science Forum, 2001, 369-372, 931-938

[18] Di Schino A., Analysis of heat treatment effect on microstructural features evolution in a micro-alloyed martensitic steel, Acta Metallurgica Slovaca, 2016, 22, 266-270

[19] Di Schino A., Di Nunzio P.E., Niobium effect on base metal and heat affected zone microstructure of girth welded joints, Acta Metallurgica Slovaca, 2017, 23, 55-61

[20] Di Schino A., Richetta M., Evaluation of metallurgical parameters effect on tensile properties in austenitic stainless steels, Acta Metallurgica Slovaca, 2017, 23, 111-121.

[21] Di Schino A., Richetta M., Effect of microalloying on quenching behaviour of steels for back-up rolls, Acta Metallurgica Slovaca, 2017, 23, 105-110

[22] Garrison L.M., Katoh Y., Snead L.L., Byun T.S., Reiser J., Rieth M., Fusion mateials research, J. Nucl. Mater., 2016, 481, 134-146

[23] Allen T.R., Gan J., Cole J.I., Miller M.K., Busby J.T, Radiation response of a $9 \mathrm{Cr}$ ODS steel to heavy ion irradiation, J. Nucl. Mater., 2008, 375, 26-37

[24] Yamashita S., Oka K., Ohnuki, Akasaka S. Ukai, S,: Mechanical behaviour of ODS steels, J. Nucl. Mater., 2002, 307-311, 283288

[25] Di Schino A., Kenny J.M, Barteri M., High temperature resistance of a high nitrogen and low nickel austenitic stainless steel, J.Mat. Science Letters, 2003, 22, 691-693

[26] Di Schino A., Barteri M., Kenny J.M., Barteri M., Fatigue behaviour of a high nitrogen austenitic stainless steel as a function of its grain size, J.Mat. Science Letters, 2003, 22, 1511-1513

[27] Di Schino A., Guarnaschelli, C., Effect of microstructure on cleavage resistance of high strength quenched and tempered steels, Materials Letters, 2009, 63, 1968-1972 